\title{
In Vitro Effects of HAS-2 Gene Silencing on the Proliferation and Apoptosis of the MCF-7 Human Breast Cancer Cell Line \\ (1)
}

\author{
Hong-Yan Zhang ${ }^{\mathrm{a}}$ Feng Liang ${ }^{\mathrm{b}}$ Fei Wang ${ }^{\mathrm{a}}$ Jian-Wei Zhang ${ }^{\mathrm{a}}$

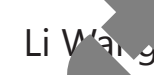
Xi-Gang Kang ${ }^{a}$ Jie Wang ${ }^{a}$ Qi-Liu Duan ${ }^{a}$

aDepartment of Oncology, PLA Army General Hospital, 'Departm Hospital of Academic of Military Medical Science, Beijing, P.R. Chin

\section{Key Words}

HAS-2 • Gene silencing • Breast cancer $• \mathrm{MCF}$
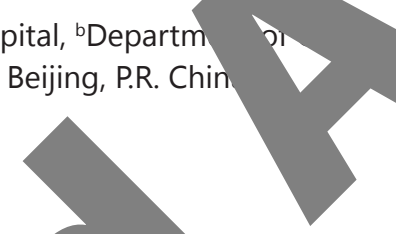

Abstract

Background: Breast cancer is chara regional lymph nodes, bone $m$ ' rrow, lc of silencing the HAS-2 gene Methods: MCF-7 cells were c siRNA groups. After transf using phase contrast $\mathrm{m}$ the mRNA and protein were performed control and the spindle shane untt clo Proli pro. $\quad n$ and apoptosis of human breast cancer cells.

and assigned into control, scrambled siRNA and HAS-2hological changes in the MCF-7 cells were observed observ the H^__-siRNA group. The HAS-2-siRNA group showed decreased expression ve to that in the control and scrambled siRNA groups. No significant differences prolit on, cell cycle distribution or apoptosis were noted between the control and Swa $n$-iRINA groups. In the HAS-2-siRNA group, the cell proliferation ability decreased init but the number of cells in the G0/G1 stage, the number of apoptotic cells and expression of caspase- 3 and caspase- 9 increased significantly. Conclusion: Our findings in ${ }^{\prime}$ te that HAS-2 gene silencing may inhibit proliferation and promote apoptosis in the -7 human breast cancer cell line.

\section{Introduction}

Breast cancer is considered to be the leading cause of cancer-related death among women all over the world [1]. It was reported that approximately 1.38 million people 


\section{Cellular Physiology Cell Physiol Biochem 2016;40:807-817 \begin{tabular}{l|l|l} 
DOI: 10.1159/000453140 & $\begin{array}{l}\text { (c) 2016 The Author(s). Published by S. Karger AG, Basel } \\
\text { www.karger.com/cpb }\end{array}$
\end{tabular} Zhang et al.: Effect of HAS-2 on MCF-7 Cells}

developed breast cancer in 2008; among all cancers, it was ranked second for morbidity, with $23 \%$ of all cancer cases, and its mortality was the fifth highest of all cancers [2]. There are many risk factors of breast cancer, such as reproductive factors, increasing age, mammographic density, family history, hereditary factors, and even environmental factors [3-5]. Due to its heterogeneous features in prognosis, molecular signature and response therapies, exploring its potential biology is essential for identifying molecular targets an novel therapeutics [6]. Heterogeneity is obvious either in the status of tumor-expressed human epidermal growth factor receptor-2 (HER2) and estrogen receptor (ER) or molecular classification schemes [7]. In addition, although advanced technical tharapies been developed, cancer metastasis still causes high mortality in breast cancer challenge in diagnosis and treatment; thus, there is considerable interest in the id of molecular processes $[8,9]$. Thus, finding the potential molecular mech ic un ing breast cancer invasion and metastasis would be beneficial for achieving surv of patients with breast cancer and a therapeutic effect.

Hyaluronan (HA) is a high-molecular-weight (HMW) polysacchari of repeated disaccharide units (D-glucuronic acid (1- $\beta 3$ ) and $K$ (1-ß4)) [10]. HA is abundantly found in the extracellul ntrix an nolved in the regulation of many cell processes such as cell migratio tion à differentiation [11]. Moreover, increased HA has been found to be associa wit vant tumors and is involved in cancer progression, including breast cancer, ov anc, gastric cancer, etc. [12-14]. The hyaluronan synthase (HAS) famil s three iso s, HAS-1, HAS-2 and HAS3 , which are integral cell membrane proteins sy vizing hya nan [15]. As one member of the HAS family, HAS-2 is also involved in syp hyaluronan and cell proliferation, cell differentiation and even cellular inflamma $\quad 1$, varticular, the inhibition of HAS-2 in tumor cells would influence the cell cycle t the wtrol cell proliferation [17]. HAS-2 has been reported to be over-expressed and HAS-2 was demonstrated to be involved in the migration and invasic on st cancer cells, suggesting that it might play a role in breast cancer metastasis [1 HAS-2 and the proliferation op-7 cells, this study used RNA interference to silence genes to observe ho nced nos-2 affects the cell proliferation and apoptosis of MCF-7 cells in breast canc

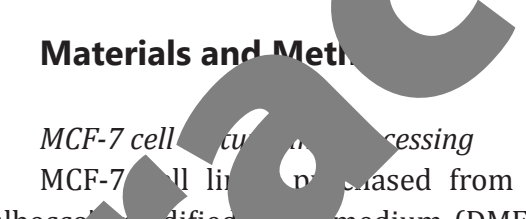

American Type Culture Collection (ATCC), were cultured in dified medium (DMEM) containing 10\% inactivated fetal bovine serum (FBS, Gibco C'mprny, Island, NY, USA), 100 units/ml penicillin (General Electric Company, USA) and $100 \mathrm{mg} / \mathrm{ml}$ mycin ral Electric Company, USA) at $37^{\circ} \mathrm{C}$ and stored in an incubator with $5 \% \mathrm{CO}_{2}$ and constant ture (T, ,rmo Fisher Scientific, California, USA). When cells reached $80 \%$ confluency, the samples with $0.25 \%$ pancreatic enzymes (Gibco Company, Grand Island, NY, USA). Cells were divided 3 groups, including the HAS-2-siRNA group, the scrambled-siRNA group (negative control) and the on group (blank control). The scrambled-siRNA had the same nucleotide composition as the HAS-2A but without distinct homology. The sequences of HAS-2-siRNA and scrambled-siRNA are shown in able 1, and both were synthesized by Shanghai GenePharma Company (Shanghai, China) after alignment using basic local alignment search tool (BLAST) from the National Center of Biotechnology Information (NCBI).

Table 1. The siRNA sequences of HAS-2-siRNA and Scrambled SiRNA

\begin{tabular}{ll}
\hline Gene & Sequence \\
\hline HAS-2-siRNA & 5'-AAAGCCTGTTTGCCTTTTTGG-3' \\
Scrambled siRNA 5'-AAAAACGGTAGATGCATCAGC-3'
\end{tabular}




\section{Cellular Physiology Cell Physiol Biochem 2016;40:807-817

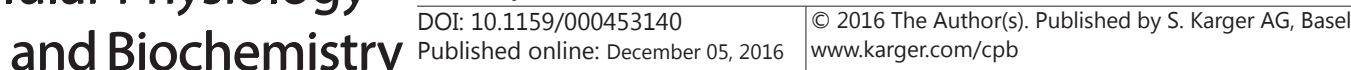 Zhang et al.: Effect of HAS-2 on MCF-7 Cells}

\section{MCF-7 cell transfection}

According to the instructions for the transfection reagent, MCF-7 cells were plated $24 \mathrm{~h}$ before transfection and were continuously incubated until 60\% 70\% confluency. Then, cells were transfected by groups. Before transfection, cells were serum starved in FBS-free DMEM solution for $1 \mathrm{~h}$. Transfection compounds were prepared for each well, in accordance with the instructions for the Lipofectamine $20^{\circ}$ kit (Invitrogen Inc., Carlsbad, CA, USA). The control group was incubated with serum-free, antibiotic-fre medium, while the HAS-2-siRNA group was incubated with serum-free, antibiotic-free medium containing HAS-2 siRNA (the final concentration was $20 \mathrm{umol} / \mathrm{L}$ ), which was enclosed in lipidosomes (Invitrogen ' Carlsbad, CA, USA); the scrambled-siRNA group was incubated with serum-free, antibiotic-free me containing scrambled-siRNA (the final concentration was $20 \mathrm{umol} / \mathrm{L}$ ) that was enclosed in $\mathrm{l}$ transfected cell cultures were blocked for $4 \mathrm{~h}$ in serum-free medium, after which $10 \%$ FBS wa the cells were cultured in a $5 \% \mathrm{CO}_{2}$ incubator at $37^{\circ} \mathrm{C}$.

Observation of living MCF-7 cells using phase contrast microscopy

After $48 \mathrm{~h}$ of transfection, the MCF-7 cells were observed under a CKX41 Olym (Olympus Optical Co., Ltd., Tokyo, Japan). The condenser phase plate was adjustea of the objective. With the eyepiece lens replaced by an assistant lens, sistant le was moved, and the condenser phase plate was adjusted to make two identical au ming after that, the assistant lens was changed to an eyepiece lens, and a phase cont ma formed. The cells were removed from the culture solution and placed on the objective microscope. Cell growth was observed, and photos we ken with rou focused on the cells.

Transmission electron microscopy

After $48 \mathrm{~h}$ of transfection, MCF-7 cells were dig a $\quad$ W Company, Grand Island, NY, USA), collected after centi tion washed with phosphate-buffered saline (PBS). Then, cells were immobilized with 2.5\% shanghai Junrui Biological Technology Co., Ltd., Shanghai, China) at $4^{\circ} \mathrm{C}$ for $2 \mathrm{~h}$ and 19 orl id (Jnanghai Junrui Biological Technology Co., Ltd.) for $2 \mathrm{~h}$. After that, cells were dehydrated $v$ hanol. Then, cells were saturated, embedded and polymerized with a mixture of e Beijing, China). Lastly, cells were n 812 resin (Beijing Hedebio Technology Co., Ltd., cyitrate (Shanghai E Micron Technologies Co., Ltd., Shanghai, China), and the cell ultrast are was ved with transmission electron microscopy (JEM100CX-II, Japan).

\section{Quantitative polymulase chain reaction ( $q R T-P C R)$}

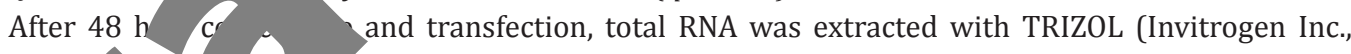
Carlsbad, CA SA), a 0 Drop 2000 (Thermo Fisher Scientific Inc., Waltham, MA) was used to detect the conc ion a ty of total RNA. A total of $0.125 \mu \mathrm{g}$ total RNA was reverse transcribed with Noloney leukemia virus reverse transcriptase (M-MLV) (Promega Corp., Madison, Wisconsin, USA). ithes AS-2-cDNA was conducted using a HAS-2-specific primer $(0.15 \mathrm{uM})$, and the sequence rimer s 5'-TTTCTTTATGTGACTCATCTGTCTCACCGG-3'. In accordance with the published gene enBank, PCR primers were designed with Primer5.0 software (Table 2) and were synthesized hangral GenePharma Company (Shanghai, China) after primer confirmation. An ABI PRISM 7500 real'CR System (ABI Company, Oyster Bay, NY) and SYBR Green I fluorescence kit (Takara Biotechnology Jalian, China) were used in the PCR reaction. The reliability of the results was evaluated with a standard rve with GAPDH as an internal reference. The CT value (amplification power curve inflection point) was

Table 2. Primer sequences for HAS-2, caspase-3, caspase- 9 and GAPDH used in quantitative real-time polymerase chain reaction

\begin{tabular}{lll}
\hline Gene & Forward & Reverse \\
\hline HAS-2 & 5'-TCGCAACACGTAACGCAAT-3' & 5'-ACTTCTCTTTTTCCACCCCATTT-3' \\
Caspase-3 5'-TGGCCAATTCTGCCATAAGC-3' & 5'-TGGTTCATCCCCATTGACTGT-3' \\
Caspase-9 5'-GGGCTCACTCTGAAGACCTG-3' & 5'-CCCGAGTGAGACTTCTGGAC-3' \\
GAPDH & 5'-TCCTGTGGCATCCACGAAACT-3' 5'-GAAGCATTTGCGGTGGACGAT-3' \\
\hline
\end{tabular}




\section{Cellular Physiology Cell Physiol Biochem 2016;40:807-817

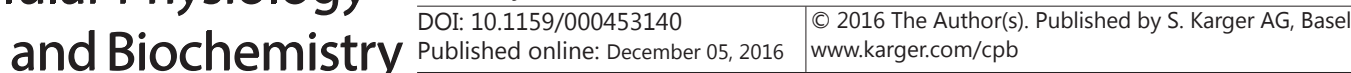 \\ Zhang et al.: Effect of HAS-2 on MCF-7 Cells}

obtained, $\Delta \mathrm{Ct}=\mathrm{CT}$ (target gene) $-\mathrm{CT}$ (internal reference), $\Delta \Delta \mathrm{Ct}=\Delta \mathrm{Ct}$ (treatment group) $-\Delta \mathrm{Ct}$ (control group); the relative expression of target genes was calculated using $2^{-\Delta \Delta} \mathrm{Ct}$.

\section{Western blotting}

After $48 \mathrm{~h}$ of cell culture and transfection, proteins were extracted, and a bicinchoninic acid (BCA) ${ }^{\prime}$ (Wuhan Boster Biological Technology Co., Ltd., Wuhan, China) was used to detect the protein concentratio After sample buffer was added to the proteins (each well, $30 \mu \mathrm{g}$ per sample), proteins were boiled at $95^{\circ} \mathrm{C}$ for $10 \mathrm{~min}$. Then, the proteins were separated using 10\% polyacrylamide gel (Wuhan Boster Biolog Technology Co., Ltd., Wuhan, China) electrophoresis, with $80 \mathrm{~V}$ electrophoretic voltage conyarted to After electrophoresis, proteins were transferred to polyvinylidene fluoride (PVDF) membr transfer-molded voltage lasting for 45 to $70 \mathrm{~min}$. Afterwards, samples were incubated at room for $1 \mathrm{~h}$ with $5 \%$ bovine serum albumin (BSA), and were incubated with primary anti-HAS-2, anti-caspase-3, anti-caspase-9 and anti-GAPDH (1: 1000 dilution) (all bou Cambridge, MA, USA), storing for one night at $4^{\circ} \mathrm{C}$. Then, samples were washed $w^{\text {in }}$ Tween 20 (TBST) 3 times ( 5 min/time). The corresponding secondary antibody w at room temperature for $1 \mathrm{~h}$, after which membranes were washed 3 times was completed with chemiluminescence reagents. GAPDH was used n internà visualized with a Bio-Rad Gel Doc EZ imager (GEL DOC EZ IM. software was applied to analyze the intensity of the target bands.

\section{Cell counting kit-8 (CCK-8) assay}

Cells were seeded into a 96 -well plate with $5000 \mathrm{ct}$ by using the CCK-8 kit according to the kit instruction $\quad$ time Institute of Biotechnology, Shanghai, China) 24, 48 and $72 \mathrm{~h}$ after culture and transfection mi s of CCK-8 reagent were added to each well, and plates were stored at $37^{\circ} \mathrm{C}$ in the incubator h. A rat, the optical density (OD) at $450 \mathrm{~nm}$ was detected with a multifunctional microplat ade $\quad$ Fisher Scientific Inc., Waltham, MA). The concentration of dimethyl sulfoxide (DMSO ea ell was no more than $0.1 \%$, and four replicate wells were set up. The above processes vere repe nd the average value was collected. The influence of HAS-2 silencing on cell prolifer viability (\%) of each group at diffe me polmus the detection index, cell viability (\%) = (experimental group OD - blank control grou $\quad$ oup OD - blank control group OD) $\times 100 \%$.

\section{Clone formation assay}

A single-cell susnonsio

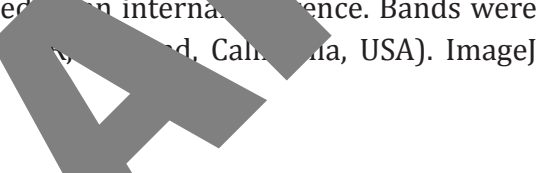

$$
\text { ., }
$$




\section{Cellular Physiology Cell Physiol Biochem 2016;40:807-817

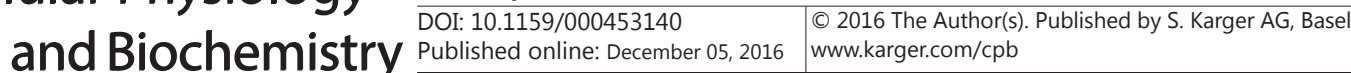 Zhang et al.: Effect of HAS-2 on MCF-7 Cells}

and $1 \mathrm{ml} \mathrm{PI/Triton} \mathrm{X-100} \mathrm{staining} \mathrm{buffer} \mathrm{(containing} 0.2 \mathrm{mg}$ RNase A, $20 \mu \mathrm{g}$ PI, 0.1\% Triton X-100) was also added into it. After being fully mixed, the solution was incubated for $30 \mathrm{~min}$ at $4^{\circ} \mathrm{C}$. Then, the cell cycle was detected with flow cytometry.

\section{Statistical analysis}

The data were analyzed with SPSS18.0 software, and measured data were expressed as ( $\pm \mathrm{s}$ ). In th measured data that exhibited a normal distribution, a $\underline{t}$ test was performed for comparisons between two groups. One-way analysis of variance (ANOVA) was used for comparisons among more than two gro' Enumerated data were expressed as a percent and ratio and were evaluated with a chi-squaro test. $P<$ indicated statistical significance.

\section{Results}

Effects of HAS-2 gene silencing on morphology of MCF-7 cells in brex After $48 \mathrm{~h}$ of transfection and observation under an inverted pha. the cells in the control group and the scrambled siRNA gr orew ac a spindle shape and with a clear nucleolus, indicating 1 from cells. In contrast, the HAS-2-siRNA group exhibited a remarkab ecr cell number, with wrinkled cells, more cytoplasmic granules, cells with a conc a deus, blistering cell membranes, more cell debris and even apopto bodies, and y cells shifting from static adherent growth to a suspended state (Fig. 1).

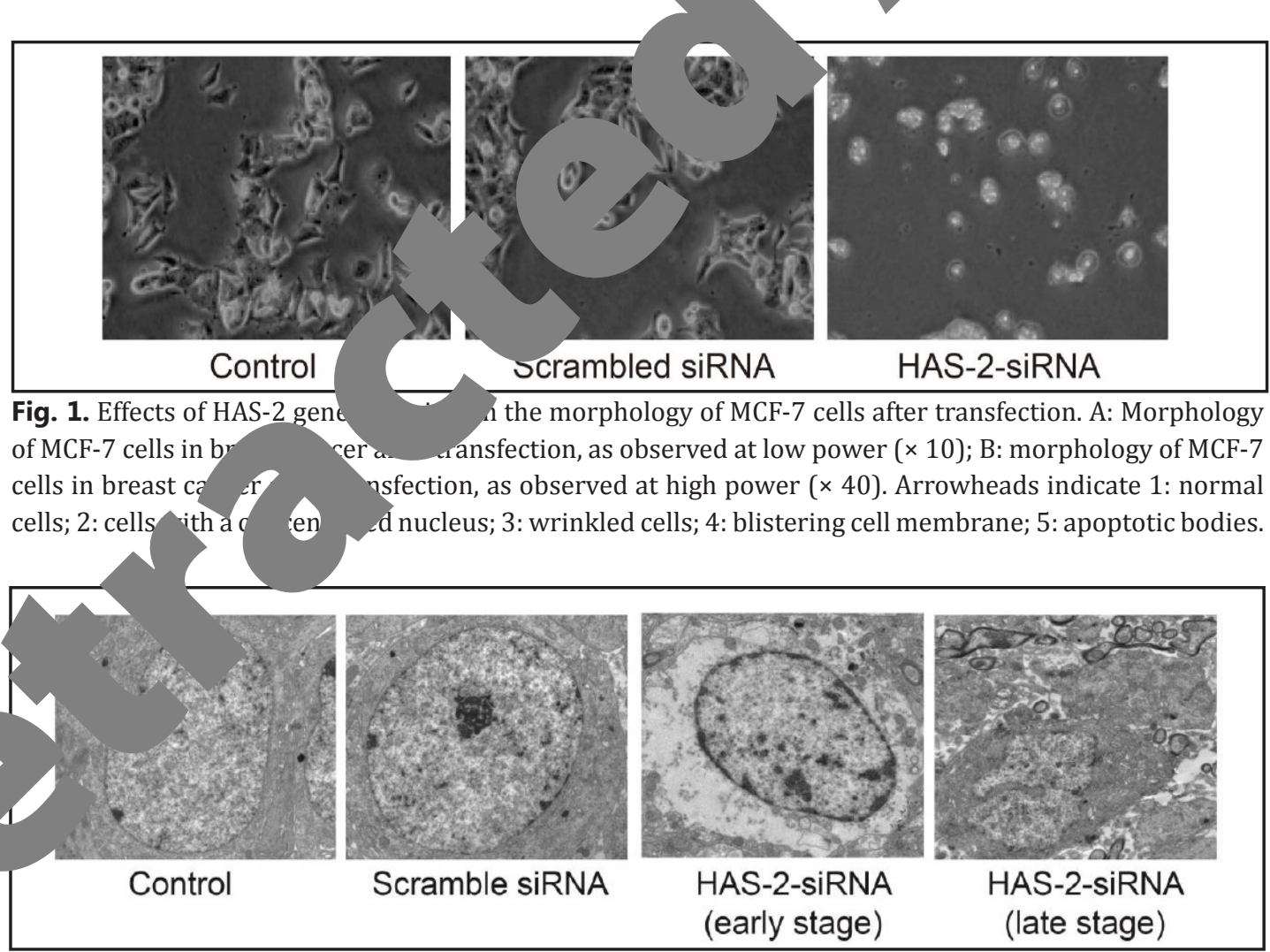

Fig. 2. Effects of HAS- 2 gene silencing on the ultrastructure of MCF-7 cells after the transfection of all groups $(\times 10000)$. A: The cells in the control group were full; B: The cells in the control group had an obvious nucleolus; C: The cells in the scrambled siRNA group were full; D: The cells in the scrambled siRNA group were rich in euchromatin; E: One indicator of early apoptotic cells in the HAS-2-siRNA group was a wrinkled cell body; F: One symptom of late apoptotic cells in the HAS-2-siRNA group was nuclear disintegration; $\mathrm{H}$ : One symptom of late apoptotic cells in the HAS-2-siRNA group was the appearance of apoptotic bodies. 

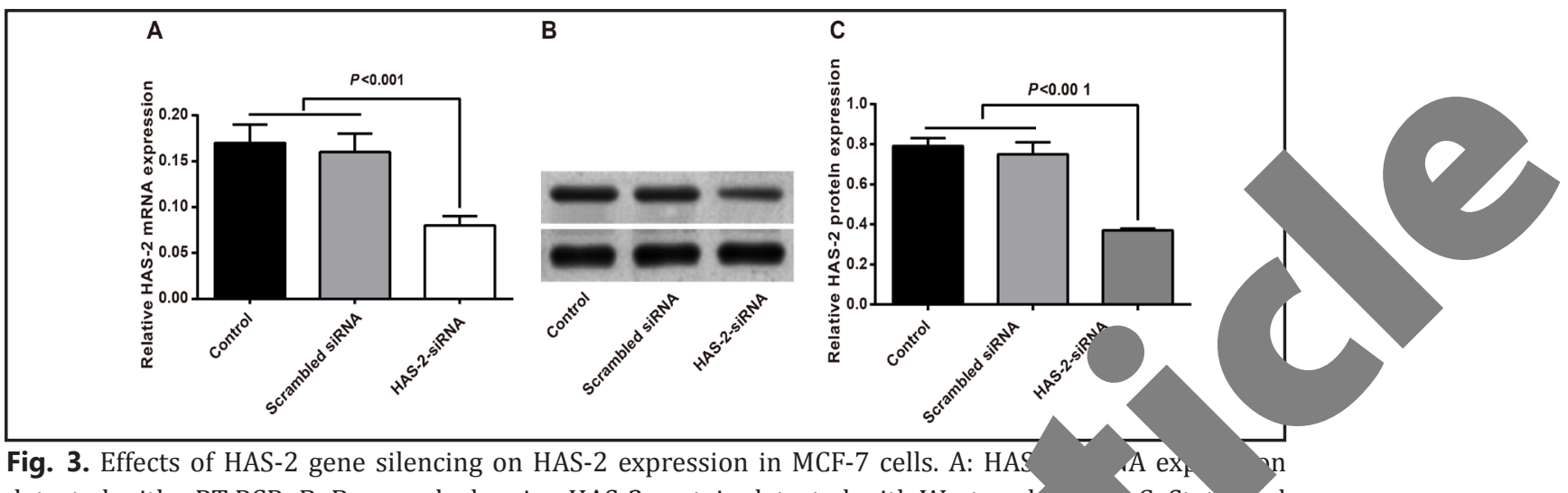

Fig. 3. Effects of HAS-2 gene silencing on HAS-2 expression in MCF-7 cells. A: HAS detected with qRT-PCR; B: Bar graph showing HAS-2 protein detected with Western $\mathbf{K}$ analysis of HAS-2 protein detected with Western blotting.

Table 3. Cell viability of each group at 24,48 and $72 \mathrm{~h}$ (\%). Notes licative of a difference from the control group, $P<0.05$; \# indicative $o^{f}$ $P<0.05$; \& indicative of a difference from the $48 \mathrm{~h}$

\begin{tabular}{|c|c|c|c|}
\hline Group & Control group & Scramblea & HAS-2-siRNA group \\
\hline Cell viability at $24 \mathrm{~h}$ & $99.84 \pm 6.51 \%$ & $98.27 \pm$ & $82.19 \pm 7.02 \% *$ \\
\hline Cell viability at $48 \mathrm{~h}$ & $99.22 \pm 6.4$ & & $69.36 \pm 6.84 \%{ }^{* \#}$ \\
\hline Cell viability at $72 \mathrm{~h}$ & $98.84 \pm 6.2$ & $6 \pm 7.2,5 \%$ & $55.53 \pm 5.41 \%{ }^{*} \# \&$ \\
\hline
\end{tabular}

Effects of HAS-2 gene silencing on MCF-7

After $48 \mathrm{~h}$ of transfection, cells wer cture after transfection g transmission electron microscopy. The cells in the control group were fy ro or oval in shape, with an irregular and large nucleus; the nucleolus was obyious; $\mathrm{tl}$ tin was abundant and the heterochromatin marginated, showing no ob po $_{1}$ rphology (Fig. 2A). In addition, the cells in the scrambled siRNA group a no significant differences in cell ultrastructure from those in the control groy yith ultrastructure and no obvious apoptotic features (Fig. 2B). However, apo sis occu. earlier in the cells in the HAS-2-siRNA group, and cells appeared to be in -apo tosis. The early apoptotic cells showed a decrease in cell body size, and the nuch. natin, which was condensed and marginated under the karyotheca, shr the rorm of blocks (Fig. 2C), while the late apoptotic cells exhibited remarkably ar ar tosis with nuclear disintegration, swelling in some mitochondria, obvious $\mathrm{p}$ icle rand a large number of vacuoles in the cytoplasm (Fig. 2D).

Effo $\quad H A S-2$ gene silencing on HAS-2 expression in MCF-7 cells after transfection

NA olated from MCF-7 cells after $48 \mathrm{~h}$ of transfection. qRT-PCR showed that as no gnificant difference in HAS-2 mRNA expression between the scrambled siRNA he control group $(P>0.05)$, while the HAS-2-siRNA group showed significantly expression of HAS-2 than the other two groups (both $P<0.05$ ) (Fig. 3A). Western
ng was employed to detect the protein expression of HAS-2 in each group, showing the protein expression of HAS-2 was consistent with its mRNA expression in all groups ig. 3B, C).

\section{Effects of HAS-2 gene silencing on MCF-7 cell proliferation}

The results of the CCK-8 cell proliferation assay after transfection for $24 \mathrm{~h}, 48 \mathrm{~h}$, $72 \mathrm{~h}$ showed that the scrambled siRNA group and the control group showed no striking difference in cell viability, regardless of time point (all $P>0.05$ ), while the HAS-2-siRNA group demonstrated a much lower cell viability than the other groups at the same time point $(P<0.05)$. The cell proliferation rate in the HAS-2-siRNA group gradually decreased and was $82.19 \pm 7.02 \%, 69.36 \pm 6.84 \%$ and $55.53 \pm 5.41 \%$ at $24 \mathrm{~h}, 48 \mathrm{~h}$ and $72 \mathrm{~h}$, respectively (all

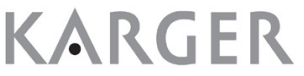



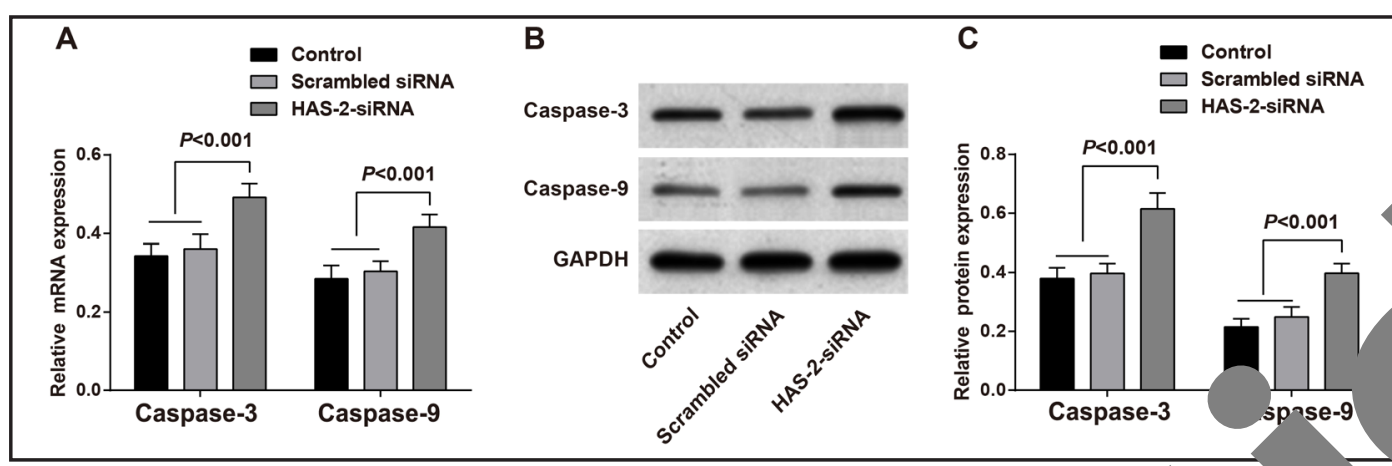

Fig. 6. Effects of HAS-2 gene silencing on the expression of signaling pathway-related ro roins, ding caspase- 3 and caspase-9, in MCF-7 cells. A: Caspase-3 and caspase- 9 mRNA expressic qRT-PCR; B: bar graph showing the expression of cleaved caspase-3 and cleaved caro ted with Western blotting; C: statistical analysis result showing cleaved caspase-3 protein, ${ }^{*}, P<0.05$ compared with the control group; qRT-PCR; quantitative reaction.

that in the other two groups (both $P<0.05$ ) (Fig. 4B). This on that silenced HAS-2 inhibited MCF-7 cell clone formation in breast cancer.

Effects of HAS-2 gene silencing on MCF-7 Ce

After MCF-7 cells were transfected and cultu. was used to detect the cell cycle changes in eac' the control group, the scrambled siRNA group while the HAS-2-siRNA group showed a G1 phase, that is, the number of cells of cells in S phase and G2/M,phase silenced HAS-2 prevented ce According to the apoptosis apoptosis rate was noted $b$ The HAS-2-siRNA grour groups (all $P<0.05$ ), an HAS-2 gene silencing co wed ifference in cell cycle distribution, hge, with most cells arrested in G0/ c. ase mineased significantly while the number er ' rotably $(P<0.05)$. This demonstrated that G1 etectu oy flow cytometry, no significant difference in twe $\quad$ ntrol and scrambled siRNA groups (both $P>0.05$ ). owed a. aficantly higher apoptosis rate than the other two e cell poptosis rate increased at later time points, indicating that promoted the apoptosis of MCF-7 cells (Fig. 5D).

Effects of $S$ vilencing on apoptosis signaling pathway-related protein expression

In $M P-7 \mathrm{C}$ (t) ofected and cultured for $48 \mathrm{~h}$, qRT-PCR detection of signaling pathwar ated 1 expression showed thas caspase-3 and caspase-9 mRNA expression yas no. ficantly different in the scrambled siRNA group and the control group, while it

ma higher in the HAS-2-siRNA group than the other two groups (all $P<0.05$ ) A). Th protein expression of cleaved caspase- 3 and cleaved caspase- 9 detected by Wes ting was in accordance with the results of qRT-PCR detection (Fig. 6B, C).

\section{Piscussion}

Breast cancer, as the most common cancer in women, affects over one million women each year worldwide [20]. It has been reported that more than $70 \%$ of breast cancer deaths are related to the colonization of cancer cells that further leads to metastasis at a secondary site, the mechanism of which, however, still remains unclear [21]. Previous studies have revealed that HAS-2 plays a critically important role in tumor progression in breast cancer cells, thus making the inhibition of HAS-2 a new therapy for anti-tumor invasion and metastasis [22, 23]. It would be of great significance to patients' overall survival and quality of life if further efforts could be made investigate the effects of HAS-2 on the invasion and metastasis of MCF-7 cells in breast cancer. 


\section{Cellular Physiology Cell Physiol Biochem 2016;40:807-817 \begin{tabular}{l|l|l} 
and Biochemistry 10.1159/000453140 & $\begin{array}{l}\text { (c) 2016 The Author(s). Published by S. Karger AG, Basel } \\
\text { www.karger.com/cpb }\end{array}$
\end{tabular} Zhang et al.: Effect of HAS-2 on MCF-7 Cells}

Having selected the MCF-7 breast cancer cell line and used RNA interference to silence genes, this study found that the HAS-2-siRNA group exhibited remarkably lower expression of HAS- 2 mRNA and protein than the control group and the scrambled siRNA group. RNA interference is described as a response to double-stranded RNA that leads to sequencespecific posttranscriptional gene silencing [24]. In regard to siRNA, it is incorporated into nuclease complex called the RNA-induced silencing complex (RISC) that targets and cleave. mRNA complementary to the siRNA and thus lowers its expression [25]. Therefore, it is assumed that, when induced by HAS-2-siRNA, the RISC-mediated cleavage of HAS-2-R results in the degradation of mRNA and leads to a decrease in mRNA expreccion, $\mathrm{w}$ further causes a decrease in HAS-2 expression due to the lack of its correspon $g \mathrm{mRN}$

It was also revealed in the study that silencing HAS- 2 can prevent cells ir from transitioning into $S$ phase by inhibiting the proliferation and clone the MCF-7 cell line in breast cancer. The cell cycle refers to a process that sp. om the d of the last cell division to the end of the current cell division, includin $\mathrm{S}, \mathrm{G} 2$, and M, in which cyclin is of vital importance for regulation r? In a a cell proliferation relies on the recurrence of the cell cycle [27]. HAS-2 ger ncing can cause a decrease in the expression of cyclins such as cyclins A and $\quad+c 2$ and thus inhibiting cell proliferation by impeding the cell division of the MCF which stuck in G0/G1 phase [28]. Moreover, silenced HAS-2 could down-regulat e e thus weakening cells' ability to proliferate and form clones [29]. Li et al. ft a'trur study that HAS-2 was over-expressed in breast cancer cell lines tive to non pnant breast cell lines and normal breast tissues and that knockdown of $\mathrm{h}$. expressio hibited breast tumor cell proliferation through the induction of apoptosis vcle arrest, which is consistent with our findings [18].

The study also reported that even silence Cell apoptosis is a complicated proces pathways, with the two main apopt pathway and the extrinsic pathway signaling pathway that induc which is often referred to as is regarded as the executi cas, ed by various factors and signaling ways being the intrinsic, or mitochondrial, d the most important caspases are caspase-3, cell apoptosis [31]. CD44, known to be a receptor for HA, constitutes a co icated,$\ldots m$ together with HAS-2 and HA for regulating cell apoptosis [32]. A study reve ${ }^{\wedge}$ ed that knockdown of HAS-2 enhanced cell apoptosis by reducing HA content and ression and promoting caspase-3 expression, while overexpression of $H$ weu nne opposite effect; the study also showed that HAS-2 partly inhibited the $\mathrm{Cl}^{+} \quad \mathrm{R}-26 \mathrm{~b}$ in suppressing cell apoptosis [33].

In cor sio hic udy came to the conclusion that HAS-2 is involved in proliferation and ap is in st cancer. In the present study, we found that it can inhibit cell $p$ olifera and promote cell apoptosis, making the silencing of HAS-2 expression a new for $\mathrm{g}$ breast cancer. However, the study was only conducted in vitro, which is to simuate a complicated physiological environment, and cannot be extrapolated vivo; additionally, the study did not investigate the regulatory mechanism of -2. merefore, more studies need to be carried out to explore the function of HAS-2 and chanism in the complicated operating system composed of HA, CD44 and caspase- 3. nermore, deeper investigation into the role of HAS-2 in a wider range of tumors is orthwhile.

\section{Acknowledgement}

The authors thank all the reviewers for their constructive criticism of this work.

\section{Disclosure Statement}

None. 


\section{Cellular Physiology Cell Physiol Biochem 2016;40:807-817

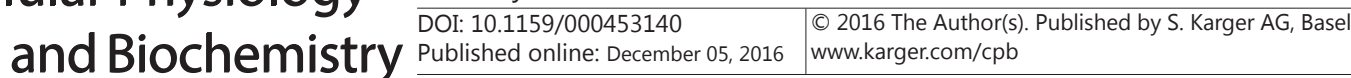 \\ Zhang et al.: Effect of HAS-2 on MCF-7 Cells}

\section{References}

1 Geng SQ Alexandrou AT, Li JJ: Breast cancer stem cells: Multiple capacities in tumor metastasis. Cancer Lett 2014;349:1-7.

2 Ferlay J, Shin HR, Bray F, Forman D, Mathers C, Parkin DM: Estimates of worldwide burden of cancer in 2008: GLOBOCAN 2008. Int J Cancer 2010;127:2893-2917.

3 Thomson AK, Heyworth JS, Girschik J, Slevin T, Saunders C, Fritschi L: Beliefs and perceptions about the causes of breast cancer: a case-control study. BMC Res Notes 2014;7:558.

4 Gray J, Evans N, Taylor B, Rizzo J, Walker M: State of the evidence: the connection between bmast canc and the environment. Int J Occup Environ Health 2009;15:43-78.

5 Coyle YM: The effect of environment on breast cancer risk. Breast Cancer Res Treat 2004;84:2

6 Higgins MJ, Baselga J: Targeted therapies for breast cancer. J Clin Invest 2011;121:379

7 Gatza ML, Lucas JE, Barry WT, Kim JW, Wang Q, Crawford MD, Datto MB, Kelley M, Mat _ evot B, . Nevins JR: A pathway-based classification of human breast cancer. Proc Natl Acad S O 6999.

8 Foubert E, De Craene B, Berx G: Key signalling nodes in mammary gland develo 1 and cancer. The Snail1-Twist1 conspiracy in malignant breast cancer progression. ${ }^{-}$Cancer $\mathrm{R}_{\mathrm{L}} \quad$ 0;12:206.

9 Sun DW, Zhang HD, Mao L, Mao CF, Chen W, Cui M, Ma R, Cao HX, Z, Wu, ang JH: Luteolin Inhibits Breast Cancer Development and Progression In Vitro and
and Regulating MiRNAs. Cell Physiol Biochem 2015;37:1693-1711.

10 Galloway JL, Jones SJ, Mossey PA, Ellis IR: The contr d importance gluronan synthase expression in palatogenesis. Front Physiol 2013;4:10.

11 Preston M, Sherman LS: Neural stem cell niches: rolec valuronan-based extracellular matrix. Front Biosci (Schol Ed) 2011;3:1165-1179.

12 Nishida Y, Knudson W, Knudson CB, Ishiguro N: An osteosarcoma cells inhibits hyaluronan rete

13 Anttila MA, Tammi RH, Tammi MI, Syrjar as, koskr SV, Kosma VM: High levels of stromal hyaluronan predict poor disease outcome in epithel Cancer Res 2000;60:150-155.

14 Setala LP, Tammi MI, Tammi p Aen PK, Agren UM, Parkkinen J, Alhava EM, Kosma VM: Hyaluronan expression in cancer cuss is associated with local and nodal spread and reduced survival rate. Br J Cancer 1 \% 9 ; 9 .

15 Kultti A, Karna R, Rilla K rminen P, Makkonen KM, Si J, Tammi MI, Tammi RH: Methyl-betacyclodextrin suppresse Juron synthesis by down-regulation of hyaluronan synthase 2 through inhibition of Akt I Riol C. 85:22901-22910.

16 Okuda H, Kor va B, vratabe M, Pai SK, Hirota S, Xing F, Liu W, Pandey PR, Fukuda K, Modur V, Ghosh A, He Hyaluronan synthase HAS2 promotes tumor progression in bone by stimul or the ra breast cancer stem-like cells with macrophages and stromal cells. Cancer Res $201 \rightarrow 37-54$

i Y, Yang T, Monterrosa Mena J, Huan C, Xie T, Kurkciyan A, Liu N, Jiang D, Noble PW: Hyaluronan nthas ulates fibroblast senescence in pulmonary fibrosis. Matrix Biol DOI:10.1016/j. tbio 20 .03 .004$.

T, Li H, Li Q Yang B, Huang J, Zhang X, Shi Y, Tan J, Ren G: Hyaluronan synthase 2 overexpression is correlated with the tumorigenesis and metastasis of human breast cancer. Int J Clin Exp Pathol 015;8:12101-12114. Heldin P, Basu K, Kozlova I, Porsch H: HAS2 and CD44 in breast tumorigenesis. Adv Cancer Res 2014;123:211-229.

20 Bai LY, Chiu CF, Chu PC, Lin WY, Chiu SJ, Weng JR: A triterpenoid from wild bitter gourd inhibits breast cancer cells. Sci Rep 2016;6:22419.

21 Kamba AS, Ismail M, Ibrahim TA, Zakaria ZA, Gusau LH: In vitro ultrastructural changes of MCF-7 for metastasise bone cancer and induction of apoptosis via mitochondrial cytochrome $\mathrm{C}$ released by $\mathrm{CaCO} /$ Dox nanocrystals. Biomed Res Int 2014;2014:391869.

22 Lien HC, Lee YH, Jeng YM, Lin CH, Lu YS, Yao YT: Differential expression of hyaluronan synthase 2 in breast carcinoma and its biological significance. Histopathology 2014;65:328-339. 


\section{Cellular Physiology \begin{tabular}{l|l|l} 
and Biochemistry $10.1159 / 000453140$ & $\begin{array}{l}\text { O 2016 The Author(s). Published by S. Karger AG, Basel } \\
\text { www.karger.com/cpb }\end{array}$
\end{tabular} \\ Zhang et al.: Effect of HAS-2 on MCF-7 Cells}

23 Udabage L, Brownlee GR, Waltham M, Blick T, Walker EC, Heldin P, Nilsson SK, Thompson EW, Brown TJ: Antisense-mediated suppression of hyaluronan synthase 2 inhibits the tumorigenesis and progression of breast cancer. Cancer Res 2005;65:6139-6150.

24 Tinoco ML, Dias BB, Dall'Astta RC, Pamphile JA, Aragao FJ: In vivo trans-specific gene silencing in fungal cells by in planta expression of a double-stranded RNA. BMC Biol 2010;8:27.

25 Kim VN: RNA interference in functional genomics and medicine. J Korean Med Sci 2003;18:309-318.

26 Lichner Z, Pall E, Kerekes A, Pallinger E, Maraghechi P, Bosze Z, Gocza E: The miR-290-295 cluster promotes pluripotency maintenance by regulating cell cycle phase distribution in mouse embryonic ste cells. Differentiation 2011;81:11-24.

27 Pascoe J, Hollern D, Stamateris R, Abbasi M, Romano LC, Zou B, O'Donnell CP, Garcia-Ocana Free fatty acids block glucose-induced beta-cell proliferation in mice by inducing cell cycle inb and p18. Diabetes 2012;61:632-641.

28 Li Y, Li L, Brown TJ, Heldin P: Silencing of hyaluronan synthase 2 suppresses the malig invasive breast cancer cells. Int J Cancer 2007;120:2557-2567.

29 Camenisch TD, Spicer AP, Brehm-Gibson T, Biesterfeldt J, Augustine ML, Calabro 4 . SE, McDonald JA: Disruption of hyaluronan synthase-2 abrogates normal cardic hyaluronan-mediated transformation of epithelium to mesenchym Invest 4

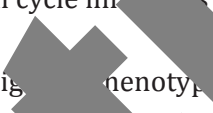

30 Syed Abdul Rahman SN, Abdul Wahab N, Abd Malek SN: In Vitro Induced by Antiproliferative Constituents from the Rhizomes of $\mathrm{C}$ Complement Alternat Med 2013;2013:257108.

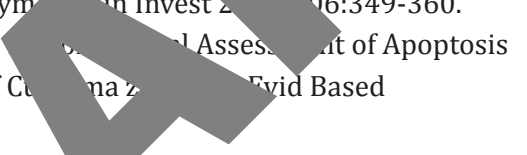

31 Azijli K, Yuvaraj S, van Roosmalen I, Flach K, Giovan E, Peters GJ, c g S, Kruyt FA: MAPK p38 and JNK have opposing activities on TRAIL-induced apop ctivation in C H460 cells that involves RIP1 and caspase-8 and is mediated by Mcl-1. Apoptoc. 18:851-860.

32 Tunjung WA, Yokoo M, Hoshino Y, Miyake Y, Kadow S, Sà ffect of hyaluronan to inhibit caspase activation in porcine granulosa cells. Biochem Biop Res C an 2009;382:160-164.

33 Liu J, Tu F, Yao W, Li X, Xie Z, Liu H, Li Q, Pan 26b enhances ovarian granulosa cell apoptosis through HAS2-HA-CD44-Casp? of ay by cargeting HAS2. Sci Rep 2016;6:21197. 